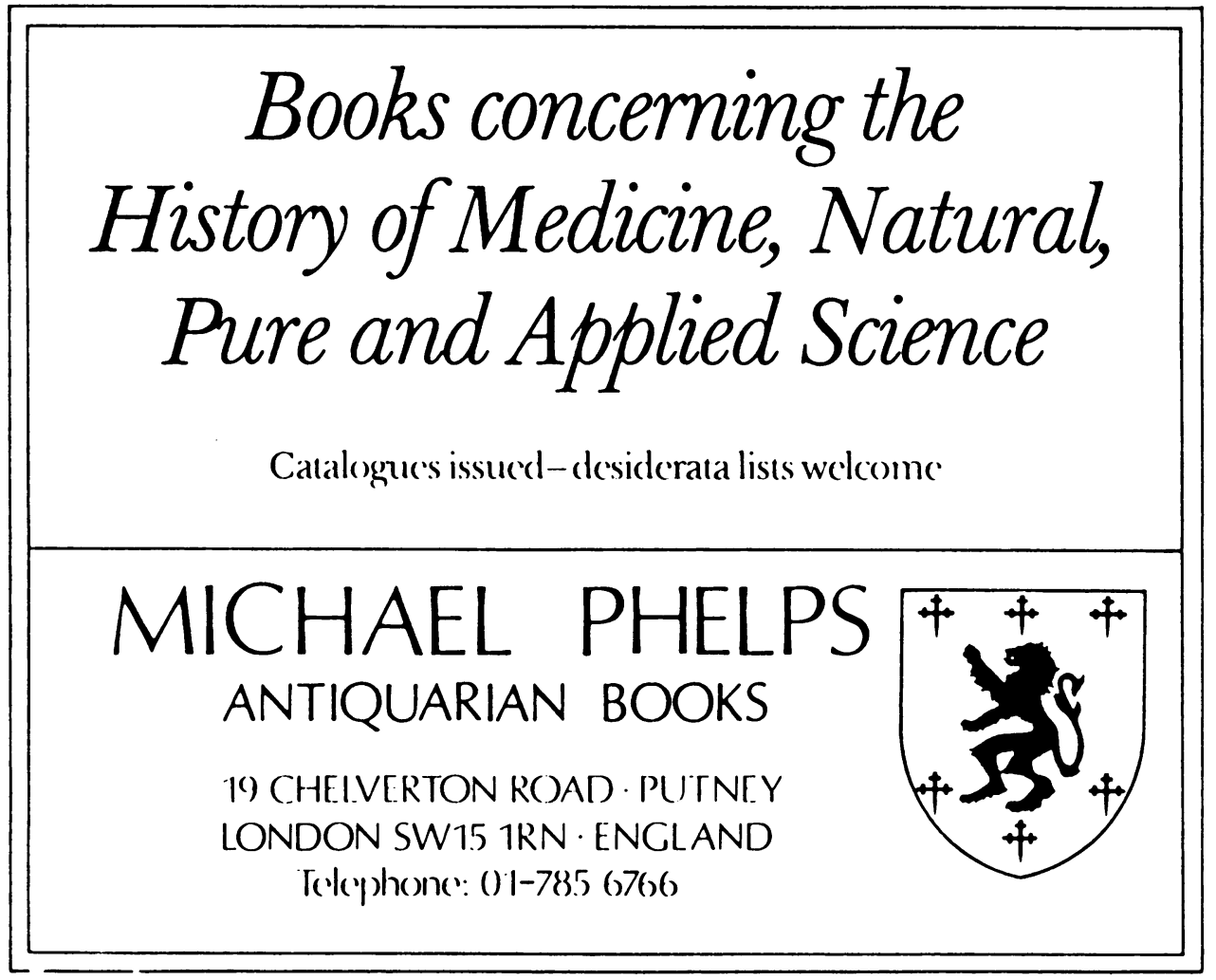

\title{
HOW TO DO IT
}

SECOND EDITION

The first edition of HOW TO DO IT proved a useful and popular guide to those things a doctor needs to know but is rarely taught: how to take an examination, how to interview and be interviewed, how to plan and write up research, how to behave at an inquest. In the second edition the original chapters have been expanded and updated, and there are several more chapters on new challenges - choosing a computer, flying, holding a press conference - and on some older ones not included in the first edition - assessing a job, dealing with a publisher.
Price: Inland $£ 6.95$

Overseas $£ 9.00 /$ USA $\$ 14.50$ including postage, by air overseas

Payment must be enclosed with order

Order from:

The Publisher

British Medical Journal, PO Box 295

London WC1H 9TE

or any leading bookseller 


\section{Journal of the History of Biology}

\section{Editor}

Everett Mendelsohn, Harvard University, Cambridge, USA

The Journal of the History of Biology is devoted to the history of the biological sciences, with additional interest and concern in philosophical and social issues confronting biology. While all historical epochs are welcome, particular attention has been paid in recent years to developments during the nineteenth and twentieth centuries. The journal serves the working biologist who needs a full understanding of the historical and philosophical bases of the field as well as serving the historian of science interested in following developments in the biological sciences.

Subscription Rates 1988, Volume 21 ( 3 issues)

ISSN 0022-5010 Institutional rate: Dfl. $225.00 /$ US $\$ 106.00$ incl. postage/handling

Private rate: Dfl. $95.00 / \mathrm{US} \$ 39.00$ incl. postage/handling An optional index of Volumes $1-20$ is also available

Private subscriptions should be sent direct to the publishers

Back Volume(s) Available

Volumes 1-20 (1968-1987)
Price per Volume

excl. postage

Dfl. 186.00/US $\$ 78.00$

plus optional index:

Dfl. $65.00 /$ US $\$ 27.00$

\section{Reidel Publishing Company}


RED-HAIR MEDICINE. The Introduction of European medicine into Japan. Edited by H. Beukers, A.M. Luyendijk-Elshout, M. Opstall and F. Vos. Amsterdam 1988. ca. 150 pp. (Nieuwe Nederlandse Bijdragen tot de Geschiedenis der Geneeskunde, Natuurwetenschappen en Techniek) ISBN: 90-6203-680-5.

ca. Hfl. 45 ,-

Contents: Harm Beukers: The fight against smallpox in Japan. The value of western medicine proved. A.M. Luyendijk-Elshout: "Ontleedinge" (Anatomy) as underlying principle of western medicine in Japan. T.M. van Gulik: Dutch surgery in Japan. G.T. Haneveld: The introduction of acupuncture into western medicine: The influence of japanese and dutch physicians. Harold E. Henkes: The influence of the dutch on japanese ophthalmology in the 19th century. A. Schouten: Jhr J.L.C. Pompe van Meerdervoort. Frits Vos: From God to Apostate: medicine in Japan before the Caspar School. Bibliography japanese-netherlands medical relations. Dutch authors. Index.

'S RIJKSKWEEKSCHOOL VOOR MILITAIRE GENEESKUNDIGEN TE UTRECHT (1822-1865). Onder redactie van D. de Moulin. Amsterdam 1988. ca. 200 pp. (Nieuwe Nederlandse Bijdragen tot de Geschiedenis der Geneeskunde en der Natuurwetenschappen) ISBN: 90-5183-015-7. ca. Hfl. 45,Inhoud: A.H.M. Kerkhoff: De militair-geneeskundige dienst en de medische hervormingen in de negentiende eeuw. A.P.M. Langeveld: Van applicatiecursus tot kweekschool. De beginjaren van de militair-geneeskundige opleiding in Nederland. H. Beukers: Bloei en kritiek. Het onderwijs onder de inspecteurs Beckers en Snabilie. F.N. Groustra: Het preklinisch onderwijs in zijn natuurwetenschappelijke aspecten. G.T. Haneveld: Het dagelijks leven der studenten. Het klinisch onderwijs. M.J. van Lieburg: De academisering van de militair-geneeskundige opleiding (1860-1880). A. de Knecht-van Eekelen: De invloed van 's Rijkskweekschool voor Militaire Geneeskundigen op de geneeskunde in Nederlandsch Oost-Indië. D. de Moulin: Abiturienten van 's Rijkskweekschool voor Militaire Geneeskundigen werkzaam in Japan. D. de Moulin: Samenvatting en conclusies. Namenregister. M.J. van Lieburg: Het 'Album studiosorum' van 's Rijkskweekschool voor Militaire Geneeskundigen.

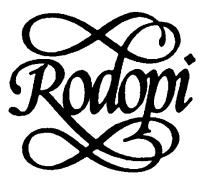

Keizersgracht 302-304

1016 EX AMSTERDAM-HOLLAND 


\section{The BMJ's new series of books of general interest by medical writers}

This enterprising new series could have no better beginning.

ROY PORTER

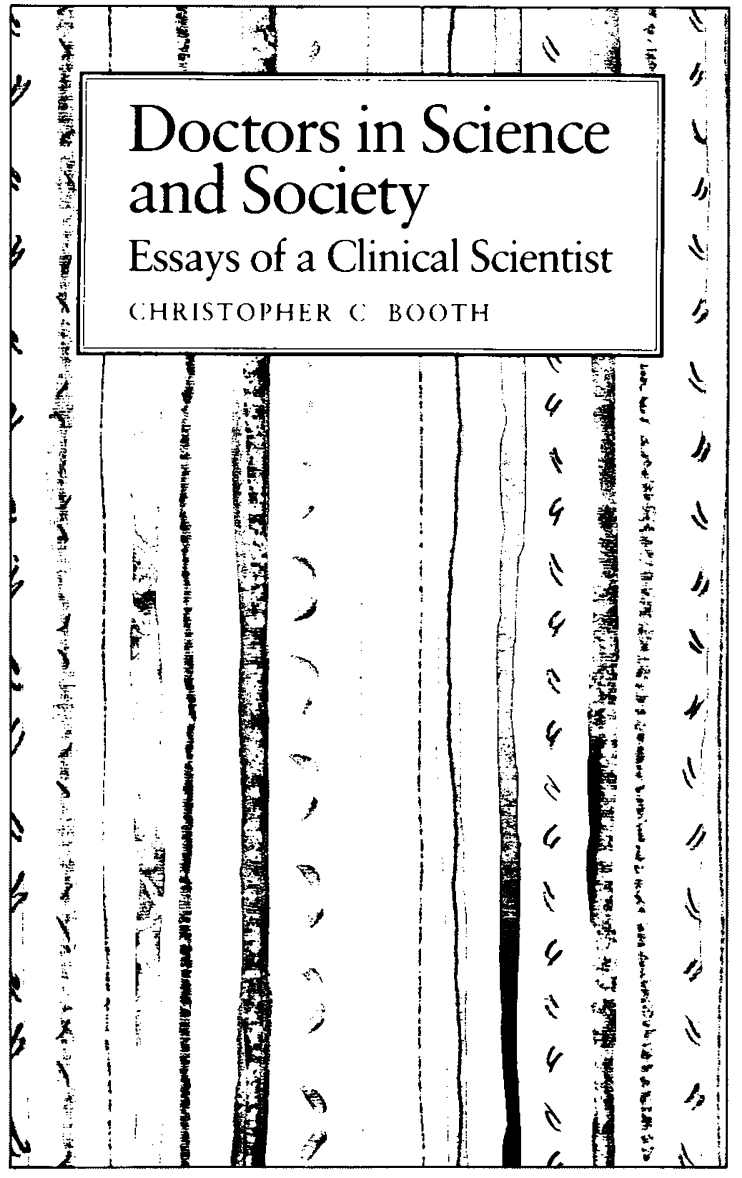

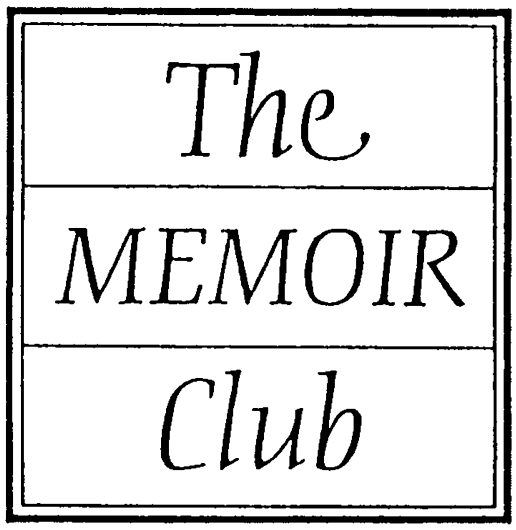

In Doctors in Science and Society Christopher Booth examines the lives and times of some eighteenth century medical scientists, among them Sir Samuel Garth, FRS, physician to the Duke of Marlborough and friend and fellow poet of Alexander Pope; and Dr John Dawson, a country practitioner and largely self taught mathematical genius, twelve of whose pupils went on to become senior wranglers at the University of Cambridge.

Not concerned only with history, Doctors in Science and Societ $y$ also considers the role of modern medical science and its relationship with technology, and the development and function of two major medical institutions, the Medical Research Council and the Royal Postgraduate Medical School. Written with elegance and authority, this fascinating collection is a must for anyone interested in the past and future of medical science.

". . . a delight to read and a pleasure to handle... At the price of a meal out it is superb value. 'Buy good books', wrote Lord Chesterfield to his son, "and read them'. I can give no better advice about this book."

The Lancet: October 101987

“. . a well written and well researched series of contributions that will give pleasure and instruction to what should be a wide readership."

Journal of the Royal College of Physicians: January 1988
Price: Inland £14.95; Abroad £19.50; USA $\$ 32.00$

$B M A$ members: Inland $£ 13.95 ; 4$ hroad $£ 18.50 ;$ USA $\$ 30.00$ (including postage, by air abroad)

Payment must be enclosed with order

\section{ORDER FROM}

British Medical Journal, .PO Box 295,

London WC1H 9TE,

or any leading medical bookseller. 
The latest Keynes Press publication marks the ninetieth anniversary of a major breakthrough in tropical medicine

This day designing God Hath put into my hand

A wondrous thing. And God Be praised. At His command,

I have found thy secret deeds

Oh million-murdering Death.

I know that this little thing A million men will saveOh death where is thy sting?

Thy victory oh grave?

Not many scientists are moved to verse by the fruits of their research, but few results are as momentous as the one celebrated by Ronald Ross in The Great Malaria Problem and its Solution. Adapted from Ross's memoirs, this Keynes Press edition gives the full story of Ross's discovery of the mode of transmission of malaria by the Anopheles mosquito. Engagingly written, it is the frank and accurate picture of four years' painstaking work, full of hope, despair, elation, frustration, and what Ross describes as the "sacred passion for discovery." It also shows the close and moving scientific partnership between Ross and Patrick Manson, the "father of tropical medicine", as evidenced in the 155 letters exchanged between thenı over this period.

Fully illustrated, and with an introduction by $\mathrm{L} J$ Bruce-Chwatt, emeritus professor of tropical public health at the University of London, this unique volume provides a fascinating insight into the process of scientific research as well as a self portrait of one of the most impressive and colourful individuals in the history of tropical medicine.
PLATE VII
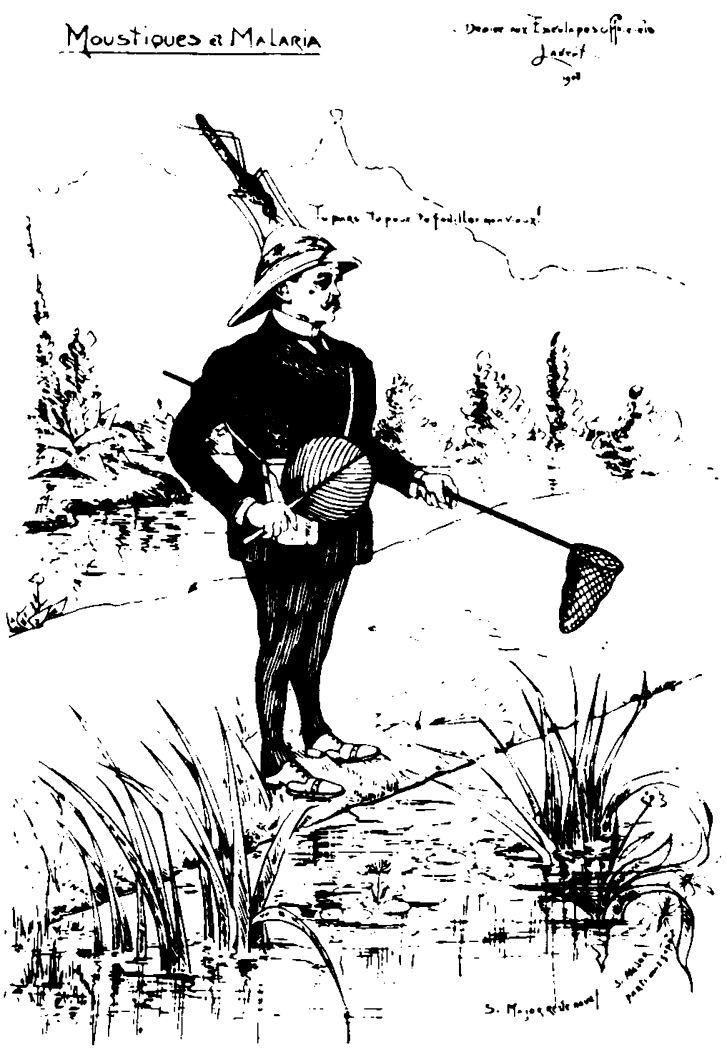

(From a Mauritian Newspaper, 1908.)

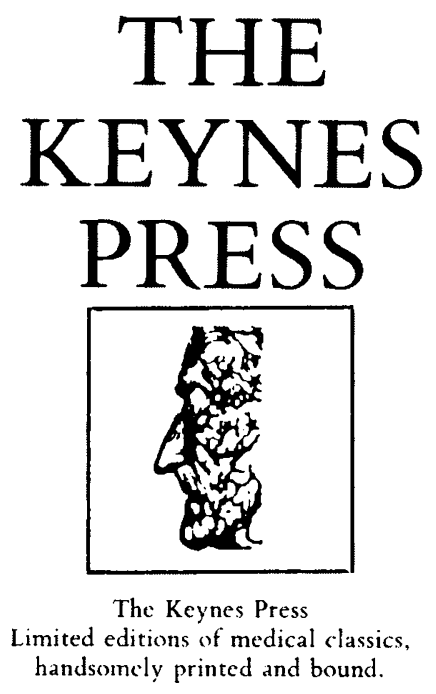

Order from:

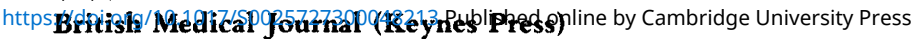

Price: Inland $\$ 45.00$; Abroad $£ 52.00$; USA $\$ 73.00$, including postage. 


\section{MEDICAL BOOKS}

Prints $*$ Portraits

\section{Old, RARe,}

\section{\& OUT-OF-Print}

\section{America's Largest Stock}

All items are fully catalogued and classified. American and European, dating from the 15th to the 20th centuries particularly classical and unusual works, with emphasis upon history, biography, and specialized medicine.

Lists issued in all fields of medicine.

We are eager to purchase small or large collections.

\section{ARGOSY BOOK STORES}

116 E. 59th St., N.Y., N.Y. 10022, PL.3-4455
F. E.

Whitehart

40 Priestfield Rd. Forest Hill

London SE23 2RS 01-699 3225

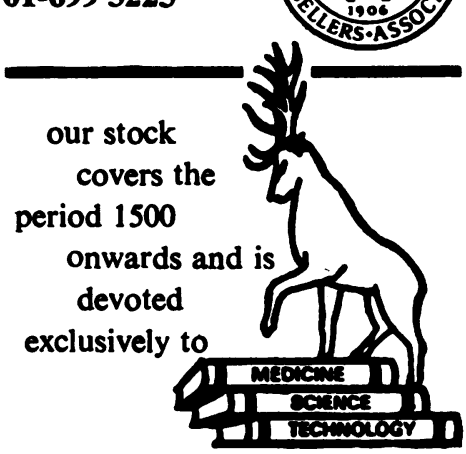

CATALOGUES ISSUED

Normal business hours or by appointment
Rare Books \& Manuscripts in the bistory of

Medicine \& the Sciences

BOUGHT · SOLD · APPRAISED

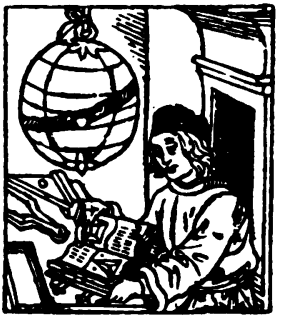

Send for our latest catalogue

Jeremy Norman \& Co., Inc.

$$
442 \text { POST STREET }
$$

SAN FRANCISCO, CALIFORNIA 94102

$$
\text { (415) } 781-6402
$$

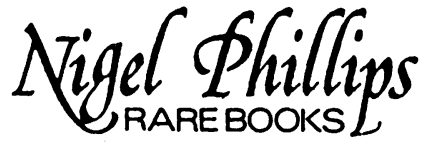

Antiquarian books in the history of medicine and the health sciences.

Please send for my catalogue, or telephone for an appointment when in London.

\section{BURLEIGH PLACE PUTNEY \\ LONDON SW15 6ES \\ ENGLAND}

Tel: 01-788 2664 